\title{
Mitos Genjer-Genjer: Politik Makna dalam Lagu
}

\section{Utan Parlindungan}

\begin{abstract}
Abstrac
Merely based on the ideological struggle, the arts play an important role, especially as a means of forming unisonality, group identification and emotional bridge between individuals in bringing "sense" that the goals of power may easily be achieved. No exception of music; it deliberately created and disseminated for the sake of its own nature. However, power is not as universal as music; making a claim toward music (songs) in the risk of political contestation may produce ambivalence meanings (ambiguity). In one hand, music tends to be sacred, but a moment later, it is more vulnerable to be alienated or marginalized. In some cases, the practice of politicization often ends up banning music and tragedy.
\end{abstract}

Keywords:

music; ideological instrument; contestation of meaning; semiotics, myth.

\begin{abstract}
Abstrak
Pada perjuangan ideologi, kesenian memainkan peran penting terutama sebagai wujud dari unisonalitas, identifikasi kelompok, dan emosi yang menjembatani antar-individu untuk merasakan bahwa kekuasaan mudah mencapai tujuannya. Tidak terkecuali dalam musik, yang secara deliberasi membentuk dan mendiseminasi bentuk awalnya. Namun, kekuasaan tidaklah universal layaknya musik. Mengklaim musik atau lagu dalam kontestasi politik yang beresiko bisa menimbulkan makna yang ambivalen atau ambigu. Di satu sisi, musik cenderung sakral, namun kemudian rentan teralienasi atau termarjinalisasi. Di beberapa kasus, praktik politisasi kerap berakhir dengan pelarangan musik atau tragedi.
\end{abstract}

\section{Kata Kunci:}

musik; instrumen ideologi; kontestasi makna; semiotik; mitos.

Sebuah artikel berjudul Bincarung, Si Kecil yang Bernyanyi Gede dalam buku bunga rampai Politik dan Post-Kolonialitas di Indonesia (Mulyana, 2003: 133-159) menceritakan Bincarung, kelompok musikal bentukan militer Orde Baru, melakukan normalisasi mental pasca peristiwa Gestapu tahun 1965..$^{1}$ Kelompok musik ini berkeliling dari kampung ke kampung di tiga kota yaitu Subang, Purwakarta, dan Cirebon. Bersafari mengampanyekan arti penting Pancasila dan UUD 1945 sebagai ideologi dan dasar negara melalui lagu-lagu bersyair.

Sebab, isu utama yang berkembang sepanjang tahun 1965-1968 menyangkut soalsoal pemulihan keamanan dan ketertiban. Selain itu, Bincarung juga diarahkan sebagai

\footnotetext{
- Alumni Jurusan Ilmu Pemerintahan, FISIPOL UGM Email: utanparlins@gmail.com

1 Gerakan September tiga puluh.
} 
upaya menetralisir suasana traumatik pasca konflik, khususnya tentang isu kemunculan kembali benih-benih komunisme di Jawa Barat. Melalui lagu bermakna "ajakan" yang menghibur, kelompok musik ini sengaja digembleng sebagai alat propaganda Orde Baru untuk membentengi masyarakat dari pengaruh komunis.

Meskipun Bincarung hanyalah kesenian rakyat yang bersifat lokal, namun mampu merepresentasikan betapa musik menjadi salah satu instrumen ideologi yang efektif, guna memengaruhi domain psikologis masyarakat. Musik, dalam ragam bentuk dan dimensinya diproyeksikan untuk kepentingan kekuasaan dengan dilabeli jargon-jargon politik tertentu. Namun, penetrasi politik dalam musik bukanlah fenomena baru di Indonesia. Jauh sebelum Bincarung, beberapa lagu daerah di Indonesia memang sengaja diarahkan untuk tujuan-tujuan kekuasaan. Salah satunya adalah lagu Genjer-Genjer.

Genjer-Genjer, sebuah lagu yang dipentaskan dalam kesenian Gandrung di Banyuwangi, pada masa Orde Lama diseret masuk ke dalam pertarungan-pertarungan ideologi. Perbedaan kedua kesenian ini hanya terletak pada nasib. Jika lagu-lagu Bincarung pada masa Orde Baru bebas dinyanyikan siapa saja, tidak berlaku sama dengan lagu GenjerGenjer. Memang Orde Baru tidak melakukan pelarangan secara resmi menyanyikan lagu Genjer-Genjer. Akan tetapi, beberapa kasus penangkapan di beberapa daerah juga melibatkan mereka yang dituduh komunis lantaran menyanyikan lagu Genjer-Genjer.

\footnotetext{
"Genjer-genjer

nong kedok'an pating keleler (dipematang

sawah berhamparan)

Genjer-genjer

nong kedok'an pating keleler

emak'e tole, teko-teko mbubuti genjer

(ibunya anak-anak, datang-datang

mencabuti genjer)

emak'e tole, teko-teko mbubuti genjer
}

\begin{abstract}
oleh sak tenong (dapat sebakul) mungkor sedot seng tole-tole (lalu bergegas pergi, dapat yang kecil-kecil) Genjer-genjer saiki wis digowo muleh (sekarang sudah dibawa pulang)

Genjer-genjer isuk-isuk didol ning pasar (pagi-pagi dijual dipasar) isuk-isuk didol ning pasar dijejer-jejer, diuntingi, podo didasar (dibariskan, diikat, dan semua digelar) dijejer-jejer, diuntingi, podo didasar emae' Jebreng (ibunya Jebreng) podo tuku nggowo welasan (pada beli membawa belasan ikat)

Genjer-genjer saiki wis arep diolah (Genjer-genjer pun sekarang siap diolah)"
\end{abstract}

Berpuluh-puluh tahun sejak peristiwa Gestapu tahun 1965, lagu Genjer-Genjer sudah tak lagi syahdu terdengar di telinga, atau dilantunkan seperti di jaman penjajahan Jepang dulu, atau bahkan sejak PKI berdiri tahun 1926 dan juga setelah memasuki fase kedua dari kebangkitannya pasca peristiwa Madiun 1948. Genjer-Genjer sebagai lagu rakyat, dibungkam sebagai anak haram sejarah dengan berbagai alasan. Ketika Orde Baru ambruk Mei 1998, nasib Genjer-Genjer tetap saja suram, sebab masyarakat masih menghakiminya sebagai lagu PKI. Bahkan di Solo beberapa tahun lalu, sebuah stasiun radio dirusak sekelompok massa hanya lantaran memutar lagu GenjerGenjer. $^{2}$

\footnotetext{
2 Kasus lain bisa diungkapkan disini, sutradara peraih Piala Citra, Hanung Bramantyo ketika film terbarunya Lentera Merah dirilis tahun 2007 kecewa berat lantaran sepotong adegan dalam film itu di sensor oleh Lembaga Sensor Film (LSF). Ketika salah satu tokoh dalam Lentera Merah, Risa Aprilianty, seorang mahasiswi pengikut aliran komunis mati terbunuh. Simbol yang digunakan Hanung untuk menunjukkan Risa seorang pengikut aliran komunis (bagian yang di sensor-red) adalah sebuah piringan hitam berisi lagu GenjerGenjer versi Lilies Suryani.

(www.detikhot.com/index.php/tainment. read/tahun/2006/bulan/05/tgl/19/time/183356/ idnews/598771/idkanal/229).
} 
Di era pemerintahan Soekarno, GenjerGenjer adalah lagu populer sebagaimana lagulagu populer lain yang seangkatan. Bahkan di berbagai kesempatan, Genjer-Genjer sering dinyanyikan musisi-musisi ternama ibukota di lingkungan istana. Lagu ini didendangkan di atas panggung nan megah serta didukung seperangkat alat musik modern. Akan tetapi, ketika rezim Orde Baru berkuasa, lagu ini ramai disebut-sebut sebagai lagu "kebangsaan" organisasi berlambang palu-arit itu. Oleh karenanya, pasca peristiwa Gestapu, lagu ini tak luput menjadi bagian yang diberangus oleh Orde Baru. Akibatnya, Genjer-Genjer pun menyusul "pencipta"-nya menuju alam baka, mengikuti masa di mana era kejayaan PKI di Indonesia harus diakhiri.

Sejarah kelam Genjer-Genjer bisa dikatakan berlangsung seiring dengan proyek mitologi komunisme yang dibangun rezim Orde Baru. Melalui media massa, Orde Baru sukses melakukan manuver politik dan sekaligus membangun wacana tandingan untuk menumbangkan ideologi komunis di Indonesia. Titik puncak yang signifikan untuk menunjukkan proyek ini masih menjadi skala prioritas Orde Baru yaitu ketika film "Pengkhianatan G30S/PKI" dirilis oleh pemerintah tahun 1984.

Film produksi $\mathrm{PPFN}^{3}$ itu muncul hampir dua puluh tahun sejak terjadinya peristiwa Gestapu. Film itu disutradarai Arifin C. Noer dan tercatat dalam sejarah sebagai film dengan budget termahal yang pernah diproduksi hingga saat ini. ${ }^{4}$ Sisi menarik dari film itu adalah visualisasi pembantaian para jenderal diselingi lagu Genjer-Genjer. Lagu itu dinyanyikan Gerwani dan Pemuda Rakyat dengan iringan tarian striptease "Harum Bunga". Film memorable yang mencekam itu rutin ditayangkan pada malam 30 September

\footnotetext{
3 Pusat Produksi Film Negara.

4 Di unduh dari laman http://www.tempo.co/read/ kolom/2014/02/14/1123/Perbandingan-Dua-FilmG30S.
}

setiap tahunnya dan baru dihentikan menjelang pengunduran diri Soeharto.

Rangkaian peristiwa di atas memberikan sedikit penjelasan bahwa Orde Baru telah menguras energi luar biasa, dengan menggunakan berbagai instrumen kekuasaan negara, demi membinasakan segala macam pernak-pernik budaya dan atribut-atribut ideologi yang berbau komunis di Indonesia. Peristiwa yang terjadi di sepanjang tahun pasca 1965, terutama setelah keluarnya TAP MPRS No. XXV 6 Juli tahun 1966, mengonfirmasi bahwa transisi kekuasaan dari Orde Lama ke Orde Baru tengah berlangsung secara dramatis.

Namun, tidak cukup kiranya bagi penguasa yang baru untuk sekedar menjalankan seremoni kenegaraan dalam proses pergantian rezim. Bagi Orde Baru, tetap diperlukan upaya yang sistematis untuk melanggengkan jalan menuju kekuasaan, sekaligus mengamankan kekuasaan dari kemungkinan kembalinya pengaruh komunis di Indonesia. Oleh karena itu, semua gelagat kaum Marxisme-Leninisme di Indonesia harus dipastikan sudah tercerabut dari akarnya.

Bahkan untuk kepentingan ilmu pengetahuan, teori, dan ajaran komunisme di kampus-kampus di kontrol super ketat oleh pemerintah Orde Baru. Sejak itu pula, semua hal yang identik dengan PKI tiba-tiba "menghilang". Seluruh aktivitas kebudayaan yang dilakukan orang-orang komunis yang menyebar di berbagai daerah praktis terhenti. Banyak dari mereka yang ditangkap, dipenjara, dan "dihilangkan" (dibunuh). Tragisnya, bukan hanya nyawa manusia saja yang dihilangkan, melainkan juga budayanya. Lagu Genjer-Genjer tidak luput dari usaha penghilangan itu karena ikut dicap sebagai produk kebudayaan PKI.

Jika dilacak kembali ke masa lampau, akar sejarah penciptaan lagu Genjer-Genjer dikatakan sama sekali tidak ada hubungannya dengan PKI. Genjer-Genjer adalah lagu rakyat populer. Ia tak lebih merupakan hasil kreasi 
M. Arief, seorang musisi Osing terkenal asal Banyuwangi. Genjer-Genjer tercipta ketika Banyuwangi di bawah penjajahan Jepang tahun 1942. Genjer-Genjer difungsikan oleh penciptanya sebagai media kritik atas penjajahan.

Setelah terbebas dari tipu daya Jepang dan menghirup udara kemerdekaan tahun 1945, M. Arief bergabung dengan Lembaga Kebudayaan Rakyat (Lekra). ${ }^{5}$ Pada titik inilah Genjer-Genjer menandakan fase terpenting riwayat nasibnya. Sebab untuk kepentingan politik, lagu Genjer-Genjer dipopulerkan oleh PKI. Selanjutnya pada tahun 1963, lagu Genjer-Genjer memasuki babak baru ketika diperdengarkan secara intensif melalui siaran RRI dan TVRI. Bahkan berkumandang di setiap kegiatan yang melibatkan anggota dan simpatisan PKI.

Hasilnya, praktik adopsi dan modifikasi atau aransemen musik Genjer-Genjer, membuat makna lagu ini pun berubah status menjadi "milik" PKI. Praktik politisasi musik tersebut telah merombak esensi maupun substansi makna lagu itu secara drastis, dari konteks kritik penjajahan Jepang ke makna paling mengerikan yaitu paham komunisme.

Oleh sebab itu, pertanyaan penting yang ingin dijawab dalam tulisan ini adalah bagaimana politik makna atas sebuah lagu bekerja? Tulisan ini akan memaparkan secara singkat sekelumit peristiwa sejarah yang berkaitan dengan perilaku musikal sebagai perilaku politik. Lalu melihat secara spesifik bagaimana Genjer-Genjer digunakan sebagai instrumen ideologi dan implikasinya terhadap kekuasaan sebelum dilarang oleh Orde Baru.

Dilanjutkan dengan interpretasi penulis terhadap teks/lirik Genjer-Genjer. Sebagai upaya rekonstruksi makna yang menjelaskan adanya kontradiksi dalam tiga fase konstruksi ideologi dominan, berkaitan dengan produksi-

\footnotetext{
5 Lekra atau Lembaga Kebudayaan Rakyat merupakan organisasi underbouw PKI.
}

reproduksi simbol "teks", baik di jaman penjajahan, Orde Lama, maupun Orde Baru. Di bagian akhir tulisan ini akan ditutup dengan refleksi mendalam sebagai upaya rehabilitasi Genjer-Genjer. Dalam karya ini, penulis menggunakan model studi hermeneutika (pendekatan fenomenologi) yang dipertajam dengan pendekatan semiotika.

\section{Melacak Penetrasi Politik dalam Musik}

Dialektika politik dalam musik diamdiam mempengaruhi kekuasaan, hal ini telah lama diyakini oleh sejumlah ilmuwan sosial. Seperti pernyataan berikut:

\begin{abstract}
"Pendidikan anak, kurikulum sekolah, acara-acara hiburan (pertunjukan musik), hubungan seks, belum lagi kepentingan ekonomi dan aktivitas ekonomi, semuanya secara potensial berhubungan dengan politik. Tetapi masing-masing dan semuanya 'pada waktu dan tempat tertentu' dan 'dibawah kondisi tertentu' yang tidak mungkin dilihat, bisa jadi mengasumsikan suatu relevansi politik..." (Macridis $\mathcal{E}$ Bernard, 2001: 11).
\end{abstract}

Musik sebenarnya barang konsumsi biasa, tidak memiliki makna yang serius hingga ia memiliki pengaruh. Meminjam istilah Ben Anderson; musik dalam bentuk lagu-lagu difungsikan untuk membentuk kesadaran aural (emosional) suatu kelompok sosial tertentu. Komunitas-komunitas terbayang, yang terpencar-pencar itu dapat dihubungkan oleh sepenggal melodi yang khas.

Petunjuk ke-tunggal-an aural komunitas terbayang acapkali menggunakan musik sebagai wahana identifikasi. Musik sebagai media untuk membangun jaringan interaksi. Sasaran utama dari kebanyakan aktivitas musik mereka, sembari mengendapkan dahulu aspek sosio-ekonomi adalah persoalan kelas dan struktur kekuasaan. 
“...Ambillah lagu kebangsaan sebagai contoh, yang dikidungkan pada hari-hari besar nasional. Takpeduli berapa dangkal syairnya dan betapa pas-pasan lagunya, toh ketika menyanyikan lagu itu kita alami keserempakan. Pada waktu yang sama, orang-orang yang sepenuhnya tak saling kenal melantunkan syair yang persis sama, mengikuti melodi yang persis sama pula. Citranya: bunyi tunggal, unisonance, menembangkan "Marseillaise", "Waltzing Matilda", dan "Indonesia Raya" memberi kesempatan unisonalitas, bagi pengejawantahan ragawi komunitas terbayang yang digemakan itu...betapa ketunggalan bunyi ini tanpa diri. Jika kita sadar bahwa orang-orang lain sedang melantunkan lagu-lagu itu persis pada saat, dengan cara, yang sama dengan kita, toh kita tidak tahu siapa sajakah mereka itu, mungkin kita sama sekali tak tahu dimana mereka berada, diluar jangkauan telinga kita. Tiada yang menghubungkan kita dengan orangorang tadi selain sepenggal nada yang dibayangkan" (Anderson, 2002: 220).

Pada fase tertentu, musik dapat diproyeksikan untuk memperlebar ruang gerak kesadaran-kesadaran politik. Musik difungsikan sebagai stimulan-vibratorian ${ }^{6}$ bagi pengejawantahan ragawi nasionalitas di banyak negara di dunia. Musik dapat tercipta karena didorong oleh kondisi sosial, politik, dan ekonomi masyarakatnya (Rachmawati, 2005: 31).

Sebut saja satu contoh, lagu Indonesia Raya garapan W.R. Supratman tahun 1924 yang "tercipta" di masa konfrontasi dengan Belanda. Lagu Indonesia Raya mampu diorganisir oleh H. Agus Salim pada saat ikrar Sumpah Pemuda, dibacakan tahun 1928. Lagu ini difungsikan sebagai akselerator utama yang mendorong semangat-semangat perlawanan di kalangan kaum muda Indonesia. Percikan api semangat

\footnotetext{
${ }_{6}$ Perangsang yang menggetarkan.
}

itu akhirnya hinggap pada titik kulminasi tertinggi, yaitu kemerdekaan 17 Agustus 1945. Lagu itu pun dikumandangkan setiap tahun sebagai lagu seremonial kebebasan, setelah sekian lama hidup teraniaya. ${ }^{7}$

Faktanya, tidak ada satu negara merdeka manapun di dunia ini yang tidak memiliki lagu kebangsaan sebagai embel-embel platform unisonalitas-nya. Bahkan di beberapa kasus, musik biasa dijadikan media penandaan atau identifikasi komunitas, institusi, kelompok kepentingan (interest-groups), atau apapun kekhasan karakter yang menjalin kontiniuitas interaksi dan ritual internal. Penandaan ini merupakan satu dari sekian banyak atribut yang dijaga dengan penuh konsentrasi, diperteguh selama mungkin, dan dimanfaatkan selama musik memang dibutuhkan oleh si-empunya musik. ${ }^{8}$

Dengan menggunakan model Easton (1957: 383-400), musik diselubungkan di tingkat asosiasi, kelompok kepentingan, dan dianggap ikut bertarung memperjuangkan ide-ide kelompok tertentu. Ide-ide itu kemudian dirangkum dalam suatu Weltanschauung, yaitu nilai kepercayaan dan keyakinan yang dimiliki oleh individu atau kelompok yang akan menentukan masa depan sikap dan perilaku politiknya.

Nilai atau ide itu, ketika bersinggungan dengan sejarah, akan muncul dalam euphoria kesejatiannya, yaitu ideologi politik (Budiardjo, 1999: 32). ${ }^{9}$ Pada praktiknya, ideologi politik

\footnotetext{
Kolonial Belanda tiga setengah abad?, dan Asia Timur Raya-nya Jepang selama tiga setengah tahun.

8 Ada kasus menarik menjelang ritual KKN di UGM. Walaupun terdengar sembraut dan kadang diselingi dengan suara-suara sumbang, mahasiswa UGM wajib hapal luar kepala dua lagu sekaligus; mars dan hymne yang tercantum di sampul paling belakang buku panduan, sebelum diterjunkan ke lokasi KKN. Lagulagu seperti itu sebenarnya memberikan kesempatan unisonalitas dan penandaan yang penting bagi almamater penulis. Betapa bangga dan bersemangatnya mahasiswa itu ketika menyanyikannya tanpa teks, dan tanpa peduli pitch-control-nya sama sekali.

9 Soal propaganda dan agitasi politik, komunisme termasuk salah satu ideologi yang sangat mendoktrin dan memiliki sifat militansi yang paling menonjol.
} 
acapkali menggunakan seperangkat instrumen untuk mencapai tujuan-tujuannya. Musik dianggap cukup strategis untuk mencapai tujuan itu. Sehingga, musik merupakan bagian penting dari sistem nilai dan sekaligus sistem simbolik karena ikut menonjolkan identitas kelompok dalam masyarakat. Namun, pengaruh musik tetap diarahkan untuk memotivasi suatu tindakan, serta mempunyai urutan hierarki atau struktur tertentu (Rudkin: 2003).

Selanjutnya, Harold Lasswell (1958: 202) menerangkan delapan sistem nilai dalam masyarakat, diantaranya adalah kualitas hidup dan ketrampilan. ${ }^{10}$ Dalam konteks ini, musik menjadi bagian penting dari sistem nilai yang sangat ditopang oleh faktor kemapanan dan pengetahuan atau pengalaman musikal seseorang, agar memiliki ketrampilan khusus di bidang musik. Konsekuensinya, dalam mencapai tujuan, ideologi politik acapkali membutuhkan orang-orang yang memang terampil di bidang musik. ${ }^{11}$

Begitupun yang diungkapkan Anderson (2002: 113):

"Jangan pula kita lupakan bahwa dalam abad yang sama (1800-an), proses vernakularisasi serupa pun berlangsung dalam bentuk lain halaman cetak; lembar-lembar gubahan musik. Sesudah Dobrovsky datang Bedrich Smetana (1824-1844) di Praha, lalu Antonin Dvorak (1841-1904), dan Janacek (1854-1928); sesudah Aasen di Norwegia tibalah Edvard Grieg (18431907); sesudah Kazinczy di Budapest datang pula Bela Bartok (1881-1945);

\footnotetext{
${ }^{10}$ Delapan nilai itu diantaranya kekuasaan (power), pendidikan atau penerangan (enlightenment), kekayaan (wealth), kualitas hidup (well-being), ketrampilan (skill), kasih sayang (affection), kejujuran (rectitude), dan keadilan (rechtschapenheid), serta keseganan (respect).

${ }^{11} \mathrm{M}$. Arief tidak mungkin menjadi seorang arranger lagu Genjer-Genjer dan anggota Lekra sekaligus, yang bergabung di dalamnya adalah para pekerja budaya, seniman dan musisi, jika tidak memiliki ketrampilan musik yang mumpuni.
}

dan seterusnya sampai ke abad kita sekarang. Semua komponis yang terkenal ini berusaha keras membuat musik yang berbau nasionalis dengan memakai lagu-lagu petani yang berabad-abad lamanya."

Oleh sebab itu, nilai resapan sebuah lagu selalu akan dihubungkan dengan konteks sejarah penciptaannya. Orang akan berkata lain ketika Genjer-Genjer hadir bukan sebagai gejala politik. Penjelasan dalam skala empiris ini tampak nyata ketika Ben Anderson (2002) menyebutkan bahwa, ada kebangkitan borjuasi komersil dan industri yang tidak merata di negara-negara yang sama.

Ada persoalan struktural dan perjuangan kelas di negara-negara maju dan terbelakang. Di dalamnya termasuk negara yang memiliki sejarah kolonialisme, kesenjangan disengaja, hubungan tak merindu dan tak mesra antara metropolis dan satelitisme. Pertarungan ideologis juga terjadi di dalamnya yaitu antara sosialisme-komunis versus liberalismekapitalistik dan konservatisme-feodalistis versus moderat-revolusioner.

Jika dirunut kembalike masa-masalampau, sejak abad ke-17, dunia sains menemukan momentum, khususnya bidang teknologi rekayasa dan informasi, untuk menapaki dunia baru yang kelak merangsang ekspedisi teritorial dan sekaligus menambah daftar panjang imperialis besar di dunia. Akibatnya, kebenaran ontologis mulai ditanggalkan sambil melempar hierarki pengetahuan kuno ke tong sampah jaman. Memori kolektif bangsa-bangsa, prinsip-prinsip keadilan, kontrak sosial yang dibawa Hobbes, John Locke, dan Rousseau ikut menyesaki wacana identitas lokal. Maka, di sinilah musik memainkan peranan pokok.

Confucius dalam Rachmawati (2005: 2-3) mengatakan bahwa dengan memahami musik yang berkembang di masyarakat, kita akan mengetahui apakah masyarakat itu terstruktur dengan baik, diperintah dengan baik, dan apakah hukum yang berlaku di masyarakat itu 
dijalankan dengan benar atau tidak. Dengan kata lain, musik menjadi indikator konflik dan juga indikator moral dan politik.

Demikian halnya dengan lagu GenjerGenjer, penjelasan-penjelasan sebelumnya dapat kita gunakan untuk memasuki dimensi politik lagu tersebut. Bahwa masyarakat di Banyuwangi mengalami satu babak sejarah penjajahan ketika Genjer-Genjer tercipta. Sama juga ketika Genjer-Genjer diadopsi oleh PKI, di tengah kecamuk perang dingin, yang kemudian dilarang oleh Orde Baru sebagai rezim pemenang kontestasi.

\section{Dari Gandrung ke Piringan Hitam}

Hanya beberapa tahun sejak runtuhnya kerajaan Blambangan tahun 1772, kesenian tradisional Banyuwangi berkembang pesat dari waktu ke waktu. Di abad ke-19, gandrung merupakan salah satu kesenian yang populer karena mengandung nilai-nilai supranatural. Lagu Genjer-Genjer lahir dari rahim kesenian ini. Saat itu, Genjer-Genjer biasa dinyanyikan dalam kesenian gandrung sebagai representasi identitas masyarakat (suku) Osing.

Gandrung Banyuwangi tidak berbedajauh dengan kesenian rakyat di daerah lain seperti tayub, ronggeng, dan cokek. Pementasannya sama-sama dalam bentuk tari dan nyanyian dengan iringan musik tertentu. Namun pada jaman penjajahan, tembang Osing lebih banyak bercerita tentang kesengsaraan bangsa yang terjajah. Lagu yang dilantunkan penari gandrung tempo dulu digunakan sebagai bahasa isyarat untuk perjuangan.

Lagu yang muncul ketika itu seperti Gending Podo Nonton menceritakan kejamnya penjajah. Beberapa lirik lagu ada yang mengungkapkan banyaknya korban yang jatuh akibat kerja paksa. Uniknya, semua lagu-lagu perjuangan itu tidak dilantunkan secara vulgar karena maknanya sengaja disamarkan. Tujuannya, untuk menghindari penciuman Belanda. Sebab jika sampai diketahui oleh penjajah, maka sang penari gandrung pasti akan langsung dibunuh.
Lagu lain yang digunakan untuk perjuangan adalah Layar Kembang. Lagu ini memberikan isyarat bahwa tentara kompeni Belanda telah mendarat di bumi Blambangan. ${ }^{2}$

Karena memiliki nilai kejuangan inilah, lagu-lagu Osing banyak diadopsi oleh partai politik pada Pemilu tahun 1955. Sebagai catatan, era 1950-an adalah babak baru bagi kebangkitan tembang Osing di Indonesia. Setelah pemilu I tahun 1955, di tengah ramainya kontestasi partai, maka seperti cendawan di musim hujan, bermunculan para pencipta tembang Osing baru. Tembangnya cenderung mewakili kepentingan politis partai politik tertentu.

Salah satu komponis terkenal saat itu adalah M. Arief dari kelompok musik Sri Muda. Selain M. Arief yang mewakili kelompok sayap kiri, muncul kelompok yang seolah menjadi saingannya, sayap kanan, meskipun jenis instrumen yang mereka bawakan sama-sama musik angklung. Persaingan ini diikuti dengan munculnya para komponis muda seperti Endro Wilis dengan lagunya yang terkenal Selendang Sutro, adapula BS Nurdian, MF Hendrik, dan termasuk Andang CY yang menciptakan lagulagu bermuatan pujian kepada partai, seperti Banteng Tangi, Kembang Melati, dll.

Tak terkecuali PKI yang terbilang partai komunis terbesar nomor tiga dunia dan partai pemenang pemilu urutan keempat saat itu. Di tangan PKI lagu Genjer-Genjer menjadi semakin populer. Pada tahun 1963, GenjerGenjer telah merambah telinga "orang Jakarta", bahkan telah diperdengarkan melalui siaran RRI maupun tayangan di TVRI. Akan tetapi, pasca peristiwa berdarah Gestapu, lagu GenjerGenjer dilarang oleh pers Orde Baru karena konon lagu itu dijadikan soundtrack dalam ritual pembantaian enam Jenderal dan seorang Ajudan A.H Nasution (Letnan Tendean) di Lubang Buaya Jakarta. ${ }^{13}$

\footnotetext{
12 http://www.cybertokoh.com/mod.php?mod=publishe r\&op=viewarticle\&artid=1178.

${ }^{13}$ A.H Nasution sendiri selamat dari percobaan pembunuhan itu.
} 
Pelarangan yang tak resmi itu disebabkan karena Genjer-Genjer dianggap sebagai lagu yang mengandung isyarat rencana pemberontakan pagi buta pada 1 Oktober 1965. Bahkan di salah satu koran yang meliput peristiwa itu menyebutkan penemuan notasi lagu Genjer-Genjer di area Lubang Buaya. Indikasi ini semakin diperkuat oleh pers Orde Baru, karena baris kedua bait awal syair lagu yang berbunyi "neng kedhokan pating keleler/di petak sawah berhamparan" diplesetkan menjadi "esuk-esuk pating keleler/di pagibuta berhamparan" (Hersri, 2003: 92).

Kasus lain juga tercatat dalam Dunia Yang Belum Sudah (1994), risalah yang ditulis oleh Hersri Setiawan, mantan tapol dan eks-Lekra Yogyakarta, yang mengungkapkan sekelumit kisah tentang lagu-lagu yang dibungkam, selain Genjer-Genjer. Di dalam buku itu tertera nama-nama tapol Pulau Buru dari kalangan seniman dan musisi seperti Subronto K Atmodjo, ${ }^{14} \mathrm{M}$ Yunanta, Go Giok Liong, dan banyak lagi seterusnya.

Hersri menuturkan pengalamannya di kamp Pulau Buru. Sensor militer terhadap hasil karya cipta para seniman, baik di panggung hiburan maupun di tempat-tempat kerja begitu ketat. Hersri mengutarakan beberapa contoh, seperti yang dialami seorang aktor dan sutradara film, Basuki Effendy, yang disiksa habis-habisan hanya lantaran menyanyikan lagu Come Back to Sorento. Sang penjaga mengartikan bahwa Basuki sedang melakukan agitasi untuk mengembalikan kejayaan PKI di Pulau Buru. Demikian juga Lie Bok Hoo yang ditempeleng penjaga militer hanya lantaran menyanyikan lagu Larilah Hai Kudaku, yang

\footnotetext{
${ }^{14}$ Perlu dicatat disini bahwa Subronto K Atmodjo adalah pencipta lagu Resopim dan Nasakom Bersatu yang kemudian hari dicap sebagai lagu-lagu komunis. Lagu Nasakom Bersatu disiapkan dalam rangka menyambut hari Sumpah Pemuda tahun 1961. Sedangkan lagu Resopim diarahkan untuk mendukung revolusi sosialisme di Indonesia. (Iqbal Thawakal; “Atjungkan Tindju Kita “, Lagu dan Sikap Politik Jaman Soekarno. Majalah Progress, No.1, Jilid 3, tahun 1993).
}

dicurigai memberi isyarat kepada para tapol untuk melarikan diri dari Pulau Buru.

\section{Perang Ideologi}

Pasca Perang Dunia II, Uni Sovyet yang komunis muncul sebagai negara adikuasa di blok Timur dan Amerika yang di blok Barat. Buruknya hubungan kedua negara ini telah membawa konsekuensi serius terhadap konstelasi politik internasional di berbagai belahan dunia, yang ujungnya melahirkan babak baru perang modern yaitu, Perang Dingin (Cold War). Tak terkecuali Indonesia, pada saat itu tampak terjepit di antara tarik ulur kepentingan dua negara ini.

Namun, kecenderungan ke sisi kiri semakin tampak dari kebijakan politik yang diambil pemerintah Orde Lama, dibawah pengaruh PKI tahun 1960-an. Tema besar yang dikampanyekan pemerintah adalah tentang kebudayaan Indonesia yang disinyalir mengalami sedimentasi akibat kapitalisme global dalam bayang-bayang neo-imperialisme Barat.

Oleh sebab itu, keberadaan sastrawan dan seniman Indonesia menjadi fokus perhatian PKI, dalam perannya sebagai agen ganda, untuk memperkuat basis ideologi komunis di Indonesia. Bagi PKI, pengaruh kapitalisme global menjadi ancaman serius bagi kebudayaan Indonesia. PKI secara terang-terangan mengibarkan bendera perang melawan segala bentuk neo-kolonialisme dan neo-imperialisme (nekolim) di Indonesia.

PKI menetapkan imperialis Amerika sebagai musuh rakyat Indonesia nomor wahid dan paling berbahaya. Bahkan, di setiap kegiatan untuk mengembangkan basis ideologinya, PKI selalu melontarkan propaganda dan agitasi politiknya tentang kebudayaan nasional dan sikap anti-Amerika-nya. Pandangan umum yang diyakini kaum komunis kala itu adalah bahwa kaum imperialis mulai dari Belanda, Inggris, Jepang, dan Amerika sedang berusaha mematikan kepribadian rakyat Indonesia. 
Amerika tidak hanya musuh secara ideologi karena kedudukan politik dan ekonominya, tetapi juga karena dominasi kebudayaanya, baik di bidang ilmu, film, musik, dan lain-lain. Kolonialisme telah merubah wujud dan sistem penghisapannya melalui jalur ekonomi dan politik. Kemudian mengintensifkan agresinya terhadap Indonesia lewat jalur budaya. Bahkan, Presiden Soekarno pada peringatan Sumpah Pemuda tahun 1959 di Surabaya telah menyerukan untuk melawan kebudayaan imperialis yang gila-gilaan seperti musik rock'n roll, musik ngak-ngik-ngok, text book thinking, dan perilaku masyarakatnya yang hedonistik. ${ }^{15}$

Peran penting seniman dan sastrawan bagi ideologi PKI terutama ditujukan dalam upaya pembentukan jiwa, semangat, kesadaran, moral, dan watak kader-kader partai dalam perjuangan revolusioner membela ideologi proletarian. Pengintegrasian seni dan sastra revolusioner dengan kaum buruh, tani, dan rakyat pekerja merupakan bagian penting dari propaganda PKI yang gencar dikampanyekan sejak tahun 1950-an.

Kaum revolusioner PKI secara sadar menggunakan kesenian rakyat dan media massa untuk keperluan agitasi dan propaganda. Politisasi seni ini diilhami oleh gerakan-gerakan sebelumnya, seperti yang sudah dilakukan oleh Sarekat Islam-SI (1912), ISDV ${ }^{16}$ (1914), dan PKI sendiri (1920). Ketika SI, ISDV, dan PKI dilarang oleh penjajah Belanda, peranan pengorganisasian dan mobilisasi massa secara terbuka dilanjutkan oleh Gerindo, PNI, dan Partindo yang dipimpin oleh Soekarno.

Dengan kata lain, ketika kegiatan partai politik dilarang oleh Belanda, kader-kader PKI banyak bergerak sembunyi-sembunyi atau

\footnotetext{
${ }^{15}$ Perlu dicatat pula bahwa gejala pelarangan terhadap lagu-lagu Koes Plus berawal dari pernyataan Soekarno itu. Koes Plus dianggap duplikat The Beatles (grup band asal Inggris), baik dari segi musikalitas maupun dandanannya. Koes Plus dicap sebagai revisionis modern produk kebudayaan nekolim.

${ }^{16}$ Indesche Social Democratische Vereeniging.
}

melakukan gerakan bawah tanah. Menyamar dalam kelompok-kelompok kesenian rakyat berupa drama rakyat dan kelompok-kelompok musik tradisional.

Pada waktu penjajahan Belanda, proses penetrasi politik ke dalam ranah seni dan sastra dengan gerakan kaum revolusioner datang dari dua aliran. Pertama, dari kaum folklore yaitu pelaku budaya dan seniman lokal yang kreatif mengintegrasikan diri dengan gerakan-gerakan revolusioner petani. Kaum ini menciptakan karyakarya kritis yang progresif untuk membangun kesadaran subjektif masyarakat agar melakukan perlawanan terhadap penjajah. Seperti misalnya ludruk, ketoprak, reog, gandrung, dll.

Lagu-lagu perjuangan memainkan peranan yang strategis dalam memompa semangat nasionalisme dan anti-kolonialisme, heroisme, dan humanisme lokal. Senimanseniman musik dan drama rakyatitu melahirkan banyak kritik sosial, terutama yang berisi satire atau sindiran. Kedua, dari kalangan intelektual yang bergerak di bidang jurnalistik, karikatur, cerpen, esai, novel, puisi, dan seterusnya.

Dapat ditebak di sini bahwa PKI dalam manifestasi ideologisnya di bidang kebudayaan lebih banyak bergerak di ranah kultural. Oleh sebab itu, wajar apabila Genjer-Genjer langsung mendapat tempat di hati kaum komunis. Genjer-Genjer hadir sebagai upaya manifestasi ideologi yang diperjuangkan oleh PKI, melalui pekerja budayanya di Lekra.

Genjer-Genjer dikatakan sebagai salah satu karya terbaik anak negeri tercipta dari tangan-tangan seniman progresif dan patriotikrevolusioner di Indonesia. Lagu ini mampu memobilisasi dan mengorganisasi semangat aural komunitas terbayangnya, dalam perjuangan revolusioner melawan kolonialisme dan imperialisme di Banyuwangi.

Faktor sejarah penciptaan dan fungsinya sebagai media perlawanan inilah yang menyebabkan Genjer-Genjer melewati jalan bertabur bunga. Usaha popularisasi pun dilakukan PKI untuk menggaungkan semangat 
revolusi kaum komunis, sambil menerapkan manifesto ideologisnya di bidang kebudayaan. RRI dan TVRI merupakan media popularisasi paling efektif dan strategis yang digunakan oleh PKI demi mewujudkan cita-cita itu.

Kemudian, artis-artis kondang pun dirangkul untuk menggaet sejumlah besar penggemar fanatiknya. Harapannya, GenjerGenjer tidak hanya disukai oleh kalangan komunis saja, tetapi juga khalayak ramai. Usaha ini terutama ditujukan kepada kaum buruh, tani dan prajurit, termasuk juga bagi para simpatisan PKI. Sebab, salah satu kenyataan yang dihadapi PKI ketika itu adalah bahwa masih banyak kaderkader mereka yang buta huruf.

Oleh karenanya, jenis musik yang akan dipilih untuk dikembangkan adalah jenis musik kultur atau folksong. Bukan musik yang rumit dan sulit dimengerti, melainkan karya-karya terbaik anak daerah yang popular, sederhana dan mudah dicerna. Oleh sebab itu, peran musisi seperti $M$. Arief yang bergabung dengan Lekra semakin signifikan di mata PKI.

Namun "di bawah kondisi tertentu", menunjukan secara faktual bahwa GenjerGenjer diagendakan, untuk apa? dan digunakan oleh siapa? Ambivalensi makna GenjerGenjer terletak di seputar dua mainstream ini. Satu sisi, Genjer-Genjer adalah musik kultur yang difungsikan sebagai media kritik terhadap kondisi sosial masyarakat yang ada di Banyuwangi. Jadi, karena ada bumbu lokalitaslah Genjer-Genjer berpengaruh dan diterima secara nasional, khususnya di telinga orang Jawa.

Sementara di sisi lain, afiliasi si pencipta lagu Genjer-Genjer dengan Lekra, menyebabkan Genjer-Genjer kembali berubah fungsi dan diposisikan sebagai lagu manifesto PKI. Akan tetapi, jangan pula kita lupakan bahwa kondisi-kondisi pasca 1 Oktober 1965 turut membidani aktualisasi kemunduran ekstrim Genjer-Genjer.

Setelah peristiwa G30S tahun 1965, kekuatan pendukung Ordebaru melakukan dua tindakan yang krusial, yaitu "budaya plesetan" dan "parodi sistem tanda". Pasca peristiwa itu, Harian Kesatuan Aksi Mahasiswa Indonesia (KAMI) yang didukung oleh kekuatan Kostrad, memplesetkan Genjer-Genjer menjadi JenderalJenderal.

Dalam catatan pribadi Hasan Singodimayan, seniman $\mathrm{HSBI}^{17}$ dan teman akrab M. Arief, menuliskan bahwa lagu GenjerGenjer telah diplesetkan:

\section{Jenderal-jenderal nyang ibu kota pating keleler \\ Emake Gerwani, teko teko nyuliki jenderal \\ Oleh sak truk, mungkir sedot sing toleh-toleh \\ Jenderal-jenderal saiki wes dicekeli Jenderal-jenderal isuk-isuk pada disiksa \\ Dijejer ditaleni dan dipelosoro \\ Emake Gerwani, teko kabeh milu ngersoyo \\ Jenderal-jenderal maju terus dipateni}

Akibat budaya plesetan itu, maka makin kuat alasan Orde Baru untuk mengeliminasi lagu ini. Pasca peristiwa G30S 1965, siapa pun yang tetap menyanyikan lagu GenjerGenjer akan ditangkap oleh aparat keamanan dan tentu saja dengan tuduhan komunis. Akibat larangan menyanyikan lagu-lagu komunis, maka beberapa seniman gandrung di Banyuwangi juga dilarang untuk menyanyikan lagu Genjer-Genjer, termasuk beberapa gendhing yang memompa kesadaran politik masyarakat. Munculnya lirik lagu Genjer-Genjer yang mendeskreditkan itu tentu saja membuat berang petinggi-petinggi militer di tubuh Angkatan Darat.

Dalam kasus ini, Genjer-Genjer memang telah difungsikan oleh PKI sebagai bagian dari political campaign. Lirik lagu yang sangat dekat dengan kehidupan rakyat kecil ini memang

${ }^{17}$ Himpunan Seniman Banyuwangi Indonesia. 
cocok dan dekat dengan ideologi komunis. ${ }^{18}$ Namun tidak boleh dilupakan, sikap politik PKI terhadap kebudayaan Indonesia justru memunculkan banyak musuh ideologi dalam negeri.

Seniman dan sastrawan kanan yang tergabung dalam Dewan Film Indonesia (DFI), KPPI dan American Motion Picture Association Indonesia (AMPAI), serempak menganggap PKI seperti onak dalam daging. Kritik pedas yang dilontarkan PKI terhadap kaum revisionis modern membuat geram kelompok kanan. Sebab, kelompok kanan pada waktu itu menganggap bahwa seni dan sastra itu memiliki nafas liberalisme dalam dirinya.

Paham liberalis yang dianut oleh seniman dan sastrawan kelompok kanan ini bertolak belakang dengan paham kiri yang dianut oleh PKI. Akibatnya, timbul friksi yang tajam di bidang kebudayaan. Persaingan antara seniman dan sastrawan kiri vis a vis seniman dan sastrawan kanan mulai bergeser ke arah pertarungan ideologis.

PKI menuduh DFI, KPPI, dan AMPAI sebagai komprador, kaum revisionis modern yang latah, kaki tangan imperialis yang tidak punya kepribadian dan penjiplak ulung. Sementara seniman dan sastrawan kanan (manikebuis) justru menganggap bahwa PKI membatasi kreativitas, membunuh kebebasan yang merupakan nafas kehidupan bagi prosesproses kreatif dan produktivitas.

Konflik dua kubu ini sebenarnya sudah meruncing sejak Manikebu dilarang oleh Soekarno atas pengaruh PKI (Hersri, 2003: 179). ${ }^{19}$ Kaum manikebuis merasa dikangkangi

\footnotetext{
${ }^{18}$ Sumber; http://gin2.info/?p=54.

${ }^{19}$ Manikebu adalah manifes atau pernyataan sikap dan pendirian kaum seniman, sastrawan, dan cendekiawan Indonesia tentang cita-cita dan politik kebudayaan nasional, dengan menegaskan Pancasila sebagai falsafah kebudayaan Indonesia. Tujuan manikebu adalah untuk menghadapi "ofensif manipolis" dibidang kebudayaan, terutama terhadap dominasi sikap dan pendirian "politik sebagai Panglima". Kecenderungan kelompok Manikebu anti-manipolis dan anti-nasakom tampak dengan diselenggarakannya Konferensi Karyawan Pengarang
}

oleh kaum manipolis. Oleh sebab itu, ketika G30S terjadi, kaum manikebuis yang tergabung dalam barisan sakit hati itu, ikut mendukung Orde Baru untuk merongrong seluruh kebudayaan-kebudayaan PKI, termasuk Genjer-Genjer yang dianggap hasil karya seniman kiri atau kaum manipolis.

\section{Tiga Rezim Tiga Mitos}

Jika memahami Genjer-Genjer hanya sebagai produk seni sebagaimana komitmen awalnya untuk menghibur, maka menyanyikan Genjer-Genjer sebagai aktivitas musik kolektif seharusnya sama sekali tidak memiliki ancaman potensi konflik. Musik bukan hanya memberikan media interaksi sosial dan ruang bebas resiko untuk mengeksplorasi perilaku sosial. Namun sebaliknya, sebuah lagu dipersepsikan berbeda apabila dipahami dalam kerangka soft politics (politik makna).

Komunikasi pesan melalui simbol "teks" di dalamnya tersimpan potensi aksi dan transaksi. Secara spesifik, musik sengaja dirangkai untuk mengeksplorasi sebuah interaksi politik karena kemanjurannya, sekaligus memiliki makna yang potensial. Sebagai perilaku politik, unsur teknis musikalitas tidak begitu penting. Makna dan isi teksnya lebih diutamakan.

Penjelasan di atas senada dengan postulat Hans Georg Gadamer (1977) yang mengatakan bahwa, dimensi seni adalah pemahaman historisitas yang harus sudah mencakup semua dimensi masa depan dari arti-arti simbolik atau teks. Gadamer mengatakan;

"Ketika kita menemukan karya seni dengan ciri khas keindahannya bukan

\footnotetext{
se-Indonesia (KPPI) pada awal Maret 1964. Presidium KPPI diketuai oleh Brigjen TNI-AD Dr. Sujono dan Bokor Hutasuhut. Manikebu ditanda-tangani oleh dua puluh seniman dan sastrawan, dan diumumkan pada tanggal 17 Agustus 1963. Atas desakan ofensif manipolis, manikebu dilarang oleh Soekarno tanggal 8 Mei 1964. Istilah Manikebu juga dipakai sebagai bahan ejekan oleh PKI dan kaum manipolis dengan memplesetkannya menjadi "mani-kebo" yang berarti sperma kerbau.
} 
wujud lahirnya. Kita akan merasa bertambah asing. Sebab karya seni berkaitan dengan kenyataan (wujud karya seni tersebut) dan persepsi banyak orang sementara itu kita sendiri secara pribadi sulit untuk menerimanya."

Mengatasi kompleksitas ini, Gadamer memformulasikan sebuah konsep yang cerdas tentang dekomparasi estetika. Suatu interpretasi tentang karya seni, apapun bentuknya yang dibuat di masa lampau, mempunyai sifat-sifat dialektis dan aktual hingga saat ini.

Melalui hermeneutika, hal tersebut bisa diatasi melalui pemahaman, penafsiran dan dialog-dialog interaktif. Penafsir dengan cara ini menempuh jalan penestapaan untuk menemukan keserasian antara si penafsir dengan objek (teks) yang sedang dikaji. Oleh sebab itu, keberadaan objek material mempunyai kekuatan yang dinamis, dalam artian bahwa karya seni tidak hanya dilihat dari aspek estetik superfisialnya saja, tetapi juga makna-makna tersembunyi atau laten yang dikandungnya.

Beragamnya apresiasi justru penting untuk meningkatkan kualitas pembacaan. Interpretasi menjadi holistik karena tidak berhenti pada satu tahapan atau satu orang penafsir saja. Secara garis besar dapat dikatakan bahwa Gadamer menawarkan tiga poros hermeneutika, yaitu penulis (pencipta teks/sejarah/seni), penafsir, dan teks dalam pengertian umum.

Penafsir merambah mulai dari pemahaman yang ada menjelang kemunculan teks, beragamnya arti sepanjang sejarah sampai pada arti di mana penafsir hidup, dan dari penafsir mencoba menyatukan rasa dengan pencipta karya atau pembuat teks. Dengan demikian, penafsiran hermeneutik adalah penafsiran yang berdialektis dan sirkuler antara penafsir, teks, dan pembuat teks.

Selanjutnya, Barthes dalam mythologiesnya (1972), menangkap forma fact dan after-the- fact dengan mengadopsi linguistik (semiotika) Ferdinand de Saussure, membongkar makna laten yang dikandung oleh objek-objek simbolik. Proses dehistorisasi, demistifikasi, deformasi atau bahkan meminjam konsep dekonstruksionisme Jacques Deridda, dijelmakan dalam kenaturalan yang disengaja dan bersifat tekstual.

Menurut Saussure, tanda itu selalu memiliki tiga wajah, yaitu tanda itu sendiri (sign), aspek material (suara, huruf, bentuk, gambar, gerak, dll) dari tanda yang berfungsi menandakan atau yang dihasilkan oleh aspek material (signify), dan aspek mental atau konseptual yang ditunjuk oleh aspek material (signified). Diformulasikan menjadi sign-signvehicle-meaning (Sunardi, 2002: 10-35).

Hal yang dicari dari sistem tanda (signification) bukanlah esensi objek pada dirinya melainkan "hanya" simulacrum (konotatif/pengganti) dari objek yang sedang diteliti. ${ }^{20}$ Sistem tanda inilah tempat potensial bagi mitos untuk menggerogoti realitas sebagai benalu-benalu sejarah. Jadi, mitologi menjadi bagian ideologi sejauh menyangkut soal sejarah, yaitu mempelajari ide-ide dalam bentuk (ideas-in-form).

Oleh sebab itu, ketika bentuk-bentuk konotatif ini sudah mapan, maka ia akan berubah wujud menjadi ideologi. Dalam sistem ideologi, untuk mempertahankan hegemoni diperlukan simbol-simbol mitos, dalam bentuk nilai. Orang atau kelompok yang paling aktif memproduksi simbol-simbol mitos

\footnotetext{
${ }^{20}$ Sebetulnya, dalam semiologi dikenal tiga jenjang pembentukan makna, yaitu penanda, pertanda, dan tanda. Penanda sebagai subjek, pertanda sebagai objek, dan tanda merupakan hasil perpaduan keduanya. Dalam linguistik (semiotika tingkat pertama), penanda diganti dengan sebutan makna, Pertanda sebagai konsep, dan tanda tetap disebut tanda. Sedangkan dalam mitos (semiotika tingkat kedua), penanda dianggap bentuk. Pertanda tetap sebagai konsep, dan tanda diganti dengan penandaan. Proses simbolisasi seperti ini bertujuan mempermudah kita dalam membedakan antara linguistik dan mitos dalam semiologi Barthesian.
} 
adalah orang atau kelompok yang berpotensi menghegemoni.

Akan tetapi, yang menguasai produksireproduksi mitos adalah orang atau kelompok yang pasti menjadi dominan. Semua ideologi bersumber dari rangkaian simbol-simbol teks yang diartikulasikan menjadi mitos (utopia, retorik, motivated). Jika Daniel Bell mengatakan, "Mari kita tinggalkan mitos dan kembali pada fakta-fakta", maka penulis mengajak pembaca untuk mengatakan, "Mari kita melihat fakta lewat mitos-mitos". Oleh karenanya, mitos kata Barthes selalu bersifat historis. Pengalaman atau pengetahuan tentang sejarah menjadi faktor kunci untuk menangkap forma dari sebuah mitos. ${ }^{21}$

\section{Pertama: Mitos Patriotik-Revolusioner Genjer-Genjer}

Genjer-Genjer harus dipahami sebagai bagian dari systems of signification (sistemsistem simbolik) yang sengaja dikonstruksi menghadapi ideologi dominan. Genjer-Genjer tercipta terutama disebabkan oleh analisis kreatif komponis dalam mengartikulasikan sistem-sistem simbolik. Penjajahan memiliki pengaruh terhadap kesenjangan sosial dan ekonomi masyarakat.

Meskipun demikian, lagu Genjer-Genjer yang digunakan sebagai media kritik masih perlu diklarifikasi. Apalagi tidak ada postulat apapun yang bisa membuktikan bahwa sebuah lagu menang melawan senjata, yang pernah

\footnotetext{
${ }^{21}$ Mitos berasal dari bahasa Yunani yaitu mutos, berarti cerita. Biasanya kita pakai untuk menunjukkan cerita fiktif yang tidak mempunyai kebenaran historis. Meskipun demikian, cerita semacam itu tetap dibutuhkan agar manusia dapat memahami lingkungan dan dirinya. Mitos-mitos ini tidak hanya kita dengar dari orang-orang yang lebih tua dan buku-buku tentang cerita lama, melainkan kita temukan setiap hari di televisi, radio, film, pidato dan sebagainya. Mitos kata Barthes adalah a type of speech determinated by its intention (jenis wicara yang ditentukan oleh intensional). Mitos mendistorsi realita sebagai efek ideologis. Esensi mitos adalah kamuflase representasi borjuis kecil sebagai fakta dari natur universal. Seperti ideologi, mitos selalu hadir dan mustahil mengelak darinya.
}

terjadi adalah sebuah lagu dapat membuat orang menemui ajalnya lebih cepat. Originalitas karya M. Arief sebagai komponis Genjer-Genjer pun masih diragukan. Bisa saja lagu ini diciptakan seseorang yang tidak terkenal sebelum M. Arief populer. Pengaruh lagu itu sebagai signified (konsep), yaitu "genjer bukan sebagai tanaman", lebih perlu kita cermati disini.

Karakter agraris penduduk Banyuwangi menunjukkan bahwa sumber-sumber ekonomi dihasilkan terutama dari sektor pertanian. Dengan demikian, masyarakat Banyuwangi akrab dengan jenis tumbuhan seperti padi, palawija, genjer, bopong, semanggi, rumput, jagung dll. Sehingga dapat dipastikan tidak ada seorang petani lokal yang tidak mengenal daun genjer.

Tanaman genjer di sini hanya sebatas objek material. Akan tetapi, ketika hadir dalam syair sebuah lagu, maka tanaman genjer dikomodifikasi menjadi identitas aural. Padahal sebagai forma, genjer dianggap sebagai tanaman bernilai ekonomi rendah. Tanaman ini dicerabut dari akarnya untuk direbus bersama dedak atau bekatul. Kemudian disorongkan ke mulut-mulut ternak.

Dengan bahasa lain, lagu Genjer-Genjer menggantikan makna denotatif "kita sedang ditindas" atau "penjajah membuat kita menjadi ternak". Kecocokan simbolik ini menjadi simulacrum bagi pengejawantahan ragawi keterjajahan itu. Genjer-genjer mempunyai fungsi representasi atas sejarah kolonialismeimperialisme.

Apabila menelaah suasana lagu GenjerGenjer, komponis tampak sedang menangkap satu fenomena yang tidak menyenangkan. Pintu inspirasinya tergedor keras-keras. Lagu ini menjadi simbol kemarahan, frustasi, dan kegelisahan yang akut. Sampai di bagian ini, ketika mendengarkan musiknya kita baru bisa mengartikulasikan kembali simbol-simbol yang coba dilukiskan komponis itu. Syair lagu ini akan mengalami kekosongan makna jika dilepas dari struktur musiknya. 
Selanjutnya, lagu ini mencoba untuk mengajak pendengarnya untuk merefleksikan kembali kehidupan keluarga miskin di Banyuwangi. Mereka berusaha bertahan hidup dengan memanfaatkan apapun yang ada di sekitarnya, termasuk tanaman genjer yang sebelumnya dianggap sebagai tanaman liar. Komponis itu melukiskan seorang ibu yang berjuang menafkahi anak-anaknya dengan berjualan daun genjer. Sila melihat syair Genjer-Genjer yang telah ditulis di halaman sebelumnya.

Walaupun dapat yang kecil-kecil dan sebakul, sudah cukup untuk dijual di pasar. Sebetulnya untuk menggambarkan realitas kemiskinan itu, agaknya komponis salah tempat ketika menghubungkan Genjer-Genjer dengan aktivitas jual-beli di pasar.

Tumbuhan genjer adalah tanaman liar. Mengapa orang miskin harus membelinya jika dapat dipetik langsung untuk dikonsumsi? Bukankah uang mereka bisa dimanfaatkan untuk membeli kebutuhan yang lain? Itulah esensi lagu Genjer-Genjer, yaitu niatan menyindir atau satire. Komponis seolah mendeformasi makna bahwa daun genjer itu memiliki nilai ekonomis yang tinggi.

Ada kegentingan naluriah untuk menjualnya sehingga seorang ibu harus pagipagi ke pasar. Daun genjer digambarkan laris manis hingga "ibunya Jebreng" harus membeli belasan ikat. Akan tetapi, "ibunya anak-anak" dapat sebakul sementara tumbuhan genjer berhamparan di pematang sawah. Barangkali komponis ingin menonjolkan kesederhanaan masyarakat tradisional itu. Menjual sesuatu yang hasilnya hanya untuk dikonsumsi, bukan orientasi laba atau akumulasi modal.

Sebab sebagai gulma, tidak ada biaya produksi yang harus dikeluarkan oleh penjual selain tenaga petik, mengikat, dan membawanya ke pasar. Nilai-nilai itu muncul tidak lebih merupakan takaran ilusif atas proses transaksi jual-beli komoditas palsu. Nilai yang sebenarnya konotatif, tidak terjamah oleh logika-logika hegemoni. Bahwa di tanah menginjak padi, orang-orang masih saja makan genjer.

Daun genjer digemari karena ongkos derita itu telah menjangkau semua lapisan masyarakatnya. Setiap dapur pernah memanjakan keluarganya dengan masakan oseng-oseng atau tumis genjer. Dua perempuan, "ibunya anak-anak" yaitu penjual dan "ibunya Jebreng" yaitu pembeli ditampilkan sebagai sosok yang tegar, sekalipun ditinggal tulang punggung keluarganya.

Sepertinya, tidak ada yang istimewa dari penggambaran komponis dalam syair lagunya itu. Secara harfiah, tidak ada indikasi distorsi berlebihan yang mengarah pada bentukbentuk konsolidasi massa, maupun semangat patriotik-revolusioner dalam lagu itu. Musik ditabuh dengan kemalasan yang semakin melemahkan jiwa. Menawarkan kesakitan yang tak kunjung sembuh. Menghanyutkan orang ke pembuangan terra incognito.

Hanya saja, semua kata disusun menggunakan cara-cara standar komunikasi sehari-hari. Muatan sastrawinya pun bisa dikatakan sangat minimalis. Penulis mengamati bahwa karakter lagu-lagu populer itu setidaknya memiliki dua ciri, yaitu syairnya sederhana dan maknanya mudah dipahami.

Oleh sebab itu, Genjer-Genjer bisa diklasifikasikan ke dalam jenis lagu daerah populer. Sekalipun simbol-simbol itu tidak terlacak, paling tidak mempunyai daya pikat atau nilai jual/komersil dan ditularkan dari telinga ke telinga. Wajar apabila Genjer-Genjer digemari masyarakat Banyuwangi. Terlebih ketika lagu itu dianggap mewakili aural penderitaan masyarakatnya. Namun, untuk dikatakan sebagai musik yang berkarakter patriotik-revolusioner, tidak ada ungkapan yang tepat untuk kita sandangkan selain mitos. ${ }^{22}$

22 Jangan pula kita lupakan bahwa sebelum Soekarno
membentuk panitia lagu kebangsaan tanggal 8
September 1944, dan sebelum Indonesia Raya ditetapkan 


\section{Kedua: Mitos Romantisme-Revolusioner Genjer-Genjer}

Tampaknya PKI mendistorsi dan mendeformasi makna Genjer-Genjer ke dalam hubungan paradigmatis, yaitu simbol virtual yang tidak nyata, utopis, dan retorik. Menghubungkan Genjer-Genjer sebagai personifikasi kaum proletar buruh dan petani. Bukan saja dari segi musikalitas lagu ini mampu menghadirkan kepedihan dan kesakitan. Melainkan juga kemampuan dialektisnya sebagai lagu petani, besar dilingkungan petani, dan mengungkapkan realitas kehidupan petani yang miskin dan tersingkir. Oleh sebab itu, penulis akan mengartikulasikan kembali hubungan paradigmatis Genjer-Genjer sebagai lagu manifesto PKI.

Di sini Genjer-Genjer tidak didengar sebagai lagu rakyat karena kepolosan, keluguan ,dan spontanitas lagu tersebut telah dinodai oleh kepentingan politik. Genjer-Genjer mengalami alienasi dari budaya otentik suku Osing di Banyuwangi. Diperkosa oleh budaya massa sebagai bentuk kontemplasi artifisial, menarik esensinya untuk tunduk pada ideologi, dan dibantu oleh kemajuan teknologi informasi seperti radio dan televisi.

Bagi PKI, Genjer-Genjer merupakan personifikasi buruh dan petani, yang dikatakan berhamparan di sawah. Artinya, "berhamparan" berkaitan dengan jumlah dan "sawah" sebagai sumber-sumber produksi. Sawah bisa saja dimaksudkan secara harfiah sebagai tempat bekerjanya petani, atau sawah sebagai pabrikpabrik tempat bekerjanya buruh.

\footnotetext{
sebagai lagu kebangsaan lewat PP No.44 tahun 1958, lagu Indonesia Raya pernah dikomersilkan tahun 1930. Lagu Indonesia Raya direkam ulang di Jerman dan piringan hitamnya diperjual-belikan di pasar-pasar Eropa dan Asia. (Wawancara RCTI dengan Roy Suryo dan pakar sejarah Des Alwi (anak angkat M. Hatta) yang ditayangkan tanggal 6 Agustus 2007). Sekedar tambahan, tanggal lahir W.R Supratman 9 Maret 1903 oleh pemerintah diperingati sebagai Hari Musik Nasional.
}

"Ibunya anak-anak" dan "ibunya Jebreng" menunjukkan strata sosial yang berbeda. Pasar disitu bisa menjadi simbol kapitalisme. "Datangdatang mencabuti genjer" mengungkapkan lemahnya posisi tawar buruh dan petani yang mudah dieksploitasi oleh para pemilik modal. Walaupun "dapat yang kecil-kecil" yaitu rakyat kecil/wong cilik dan "sebakul" atau sedikit, namun tetap memiliki nilai jual bagi "ibunya anak-anak".

"Dibariskan, diikat, dan semua digelar" merupakan ekspresi ketertindasan dan ketidakberdayaan kaum buruh dan petani. Ketika kita mengacu pada rivalitas PKI, "ibunya anak-anak" bisa juga dikategorikan sebagai kelompok revisionis modern, kaum borjuis feodal atau kapitalis birokrat/kabir, dan kaum manikebuis. ${ }^{23}$

Ada eksploitasi yang dilakukan "ibunya anak-anak" terhadap buruh dan petani untuk dijual kepada "ibunya Jebreng". Tampaknya, "ibunya Jebreng" cocok digambarkan dengan imperialis Amerika dan negara-negara asing lainnya. Perdagangan tenaga buruh dan petani tersebut sama dengan menjual bangsa ini kepada para imperialis.

Terlebih lagi, PKI juga berkepentingan memobilisasi kekuatan buruh dan petani, teristimewa suku Jawa, baik di Pulau Jawa dan luar Jawa, untuk merefleksikan kedirian mereka tentang ketertindasan lewat syair Genjer-Genjer itu. Mengampanyekan sosialisme-proletar tidak cukup hanya melalui provokasi dan doktrinasi lewat mimbar bebas yang berapiapi, membakar semangat agar merapatkan barisan untuk aksi-aksi perlawanan dan pemberontakan.

Hati mereka yang tertindas dan menderita perlu disentuh dengan musik-musik melankolis. Intinya, PKI ingin menegaskan pesan-pesan politiknya lewat lagu Genjer-Genjer bahwa

\footnotetext{
${ }^{23}$ Dalam makna konotatif, ibu bisa berarti induk, kota, tanah, seperti ungkapan ibukota, ibu pertiwi, ibu negara. "Ibunya anak-anak" bisa juga kita analogikan tokoh-tokoh dalam negeri.
} 
perasaan yang dialami buruh dan petani sama dengan yang dirasakan oleh PKI.

Apabila maksud ideologis itu tidak terbaca (unidentified), menyajikan GenjerGenjer kedalam piringan hitam dapat menjadi penghasilan tambahan untuk mengembangkan "sayap kiri" di Indonesia. Dengan kata lain, lagu Genjer-Genjer sebagai manifestasi romantismerevolusioner PKI dan Lekra adalah mitos.

\section{Ketiga: Mitos Stigma-Historis Genjer- Genjer}

Pasca tragedi Gestapu, pers Orde Baru menurunkan berita tentang ditemukannya secarik kertas yang berisi notasi lagu GenjerGenjer di areal Lubang Buaya. Pers tersebut diantaranya adalah koran Pantjasila, koran Angkatan Bersenjata, dan Berita Yudha pada tanggal 4 Oktober 1965. Notasi yang ditemukan itu dikatakan mengandung indikasi pemberontakan PKI tanggal 30 September 1965. Secarik kertas itu yang kemudian dijadikan bukti kuat oleh Orde Baru.

Anehnya, syair lagu yang terdapat di kertas itu tidak sesuai dengan syair lagu yang sebenarnya. Sejarah tidak pernah mencatat bahwa secarik kertas, yang dianggap remehtemeh, yang berisi bait lagu bisa menjadi milestone bagi munculnya rumor keterlibatan PKI dalam G30S. Padahal alibi itu diperkuat oleh Harian Kesatuan Aksi Mahasiswa Indonesia yang didukung oleh kekuatan Kostrad dengan memplesetkan Genjer-Genjer menjadi JenderalJenderal.

Apabila boleh mengira-ngira, mengapa penemuan secarik kertasitu menjadi fenomenal? Kertas yang hanya berisi bait lagu, bukan memo, surat atau objek lain yang tercecer, misalnya bendera palu-arit. Bukan pula menangkap dan menginterogasi seseorang yang tahu tentang rencana pembunuhan para jenderal.

Dengan logika sederhana, Genjer-Genjer sudah mewakili simbol-simbol PKI. Bagi Orde Baru sudah cukup indikasi kuat untuk menjatuhkan justifikasi awal atas keterlibatan
PKI, di dalam gerakan pemberontakan yang dimotori oleh Letkol Untung, dkk itu. Tanpa disadari, perlahan-lahan mitos sedang diproduksi.

Tak dapat dipungkiri bahwa struktur dominasi elite sangat tergantung pada kemampuannya merekayasa sejarah, serta ketaatan masyarakat yang menjadi objek hegemoninya. Sekalipun kekuatan rezim dapat mengendalikan kekuasaan negara, selalu diperlukan mitos-mitos yang secara intensional mampu memproduksi legitimasi bagi status quonya.

Adolf Hitler (1889-1945) dalam bukunya yang terkenal Mein Kampf (Pejuangku) mengatakan, "Kebohongan, asal besar dan terus diulang-ulang akan menjadi kebenaran juga akhirnya." ${ }^{24}$ Oleh sebab itu, artikulasi sistemsistem simbolik bagi rezim Orba merupakan proses kreatif mitos untuk membangun realitas yang tampak sangat natural.

Orde Baru secara implisit memproduksi mitos tandingan agar kelompok oposan dominan tidak diakui lagi eksistensinya. Media memiliki peran strategis dalam proses produksireproduksi mitos tersebut. Media mampu menggiring masyarakat untuk membentuk opini yang seragam. Masyarakat yang terjebak akan langsung terkungkung oleh dusta-dusta sejarah.

Seperti virus, kesadaran individu mengenai kekuasaan Orba sangat tergantung pada anti-biotik yang diproduksi oleh media. Jika anti-biotik itu tidak diproduksi atau gagal membunuh virus, maka perkembangan virus akan merajalela dan menyerang sistem kekebalan rezim. Akibatnya adalah

\footnotetext{
${ }^{24}$ Buku itu sangat terkenal di Munich, Jerman dan dijadikan kitab suci bagi kaum National-Sozialism (NAZI). Inti dari buku itu berbicara tentang antisemitisme, pengagungan terhadap kekuasaan negara, pelecehan moralitas dan strategi menguasai dunia. Selain itu, ada cerita yang menarik menyangkut tema kita kali ini. Merit (2003) menjelaskan bahwa Hitler, yang memahami pengaruh kekuatan musik dan lagu-lagu, sering menggunakan musik Richard Wagner untuk memicu perangai agresif para serdadunya.
} 
keberlangsungan eksistensi rezim akan terancam.

Krishna Sen dan David T Hill (2000) menyebutkan ada tujuh pilar yang dianggap paling strategis memproduksi kekuasaan hegemoni (mitos). Ketujuh pilar itu adalah buku, pers, radio, televisi, sinema nasional, industri musik, dan internet. Akan tetapi, bagi Orde Baru yang paling strategis untuk membangun mitologi tentang PKI adalah pers, radio, televisi dan sinema nasional.

\section{Kesimpulan}

Pertarungan ideologi, mau tidak mau juga merupakan pertarungan simbolik. Ketika Genjer-Genjer digunakan sebagai salah satu instrumen ideologi, maka secara tidak langsung lagu itu dianggap ikut bertarung menghadapi ideologi lawan. Pada saat yang sama, GenjerGenjer akan sulit keluar dari pengasingan (out of exile) dan terjebak dalam restriktif ideologi atau stigmatisasi.

Genjer-Genjer menjadi kode-kodejawaban (codes respons) dan apabila kemenangan ada di pihak lawan, maka lagu itu dipaksa mati suri. Di titik inilah muncul ambivalensi makna akibat kontestasi nilai-nilai dalam memandang kebudayaan nasional. Jadi, pelarangan GenjerGenjer bukan disebabkan nilai artistik lagu itu, namun lebih pada hubungan lagu itu dengan ideologi dan struktur sosial masyarakat yang luas. Secara disengaja, Genjer-Genjer adalah gejala penyimpangan makna yang diproyeksikan untuk tujuan-tujuan politik dan ekonomi.

Nasib lagu itu lebih banyak ditentukan oleh pertarungan dominasi hegemoni politik antara Orde Lama dan Orde Baru. Bukan lagi pada fitrahnya sebagai lagu rakyat yang seyogyanya diletakkan di aras terhormat kultural. Genjer-Genjer telah diperkosa dan dinodai oleh kepentingan elite untuk menggalang opini-opini publik, dengan kontrol media massa seperti pers, radio, dan televisi.
Pada saat itu, media massa dijadikan kendaraan politik elite untuk mendistorsi realitas sosial. Genjer-Genjer diartikulasikan kembali ke dalam mindset masing-masing aktor, dengan cara membengkokkan sejarah dan memutar-balikkan fakta-fakta. Kesadaran masyarakat dipermainkan oleh fobia artifisial yang sengaja dibentuk untuk memenangkan pertarungan.

Universalisme yang dikandung dalam musik bisa dikatakan hanyalah bualan kosong, jika dihadapkan pada pertarungan-pertarungan ideologis. ${ }^{25}$ Di sinilah paradoks terbesar musik dalam politik. Ketika eksistensi musik berada dalam radar-radar pertarungan elite politik di masyarakat, internalisasi justru menyebabkan musik kehilangan ruang-ruang universal.

Ketika superioritas kekuasaan mulai gaduh, kemenangan ordo penguasa perlu membentengi diri dari para agresor politik. Maka seluruh pernak-pernik subordinat atau oposan yang menyimpang dari langgam kekuasaan akan segera dibungkam dan dikirim ke dunia para arwah (Mortimer, 1974: 366-367; Robert, 1990: 23-24). ${ }^{26}$

Diera Orde Baru (1966-1998), menyanyikan Genjer-Genjer adalah bid'ah, larangan terkutuk yang menyetarakannya seperti hukum Tuhan, dalam kitab-kitab suci agama samawi. Contohnya bila membandingkan Timor-Timur sebelum dan sesudah merdeka dari NKRI,

\footnotetext{
${ }^{25}$ Universalisme musik artinya setiap ras, kelas, agama, etnis, profesi, umur dan faktor-faktor pembeda lainnya berhak mengapresiasi musik menurut sudut pandangnya masing-masing.

${ }^{26}$ Kurun waktu 1965-1968, diperkirakan ada ratusan ribu atau bahkan jutaan orang yang tewas akibat pembantaian anggota dan sejumlah aktivis PKI di berbagai daerah. Itupun belum termasuk orang yang tewas lantaran menyanyikan lagu Genjer-Genjer. Akan tetapi, perkiraan itu belum final dan masih spekulatif. Lagipula penyaji angka-angka korban pembantaian itu kebanyakan adalah publikasi para peneliti asing. Menurut hitung-hitungan Rex Mortimer, ia menyebutkan bahwa jumlah anggota PKI dan onderbouw-nya seperti Pemuda Rakyat, SOBSI, BTI, Gerwani, "Lekra", dan HIS mencapai angka dua puluh juta orang.
} 
pasca jajak pendapat 1999 merupakan satu hal yang absurd untuk menyanyikan lagu Indonesia Raya untuk memperingati hari kemerdekaan Timor Leste.

Orang pun tak peduli ketika lagu GenjerGenjer bertengger di chart paling atas tangga lagu radio-radio dan menjadi hit favorit. Ambivalensi ini tampak diacuhkan saat GenjerGenjer, selama empat dasawarsa, tenggelam melewati fase anomi. Terbuang percuma hingga digiring ke peristirahatan terakhir, menemukan aktualisasi kemundurannya. Genjer-Genjer disingkirkan begitu saja, tanpa belas kasihan dan tanpa pembelaan sama sekali, meski rezim Orde Baru ambruk 21 Mei 1998 silam dan tongkat estafet kekuasaan telah empat kali digulirkan. ${ }^{27}$

\section{Daftar Pustaka}

Anderson, Benedict. (2002). Imagined Communities. Yogyakarta: Insist-Pustaka Pelajar.

Barthes, Roland. (1972). Mythologies. New York: Hill and Wang.

Budiarjo, Miriam. (1999). Dasar-Dasar Ilmu Politik. Jakarta: PT Gramedia Putakatama.

Macridis, Roy. C dan Brown, Bernard E. Perbandingan Politik (Edisike-enam). Jakarta: Erlangga.

Cribb, Robert. (1990). The Indonesian Killings 1965-1966. Australia: Monash University.

Easton, David. (1957). An Approach to The Analysis of Political System. World Politics.

Gadamer, Hans Georg. (1977). Die Aktualitat des Schonen: Kunst als Spiel, Symbol und Fest. Germany: Stuttgart.

Lasswell, Harold D. (1958). Politics, Who gets What, When, How. New York: World Publishing.
Merrit. (2003). Simfoni Otak. Bandung: Kaifa.

Mortimer, Rex. (1974). Indonesian Communism Under Sukarno. Itacha and London: Cornell University Press.

Mulyana. (2003). Bincarung: Si Kecil yang Bernyanyi Gede. Politik dan Post-Kolonialitas di Indonesia. Yogyakarta: Kanisius.

Rachmawati, Yeni. (2005). Musik sebagai Pembentuk Budi Pekerti. Yogyakarta: Panduan.

Rudkin, J.K. (2003). Community Psychology: Guiding Principles and Orienting Concept. New Jersey: Prentice Hall.

Sen, Krisna dan Hill, David T. (2000). Media, Budaya dan Politik di Indonesia. Institut Studi Arus Informasi: ISAI.

Setiawan, Hesri. (2003). Kamus Gestok. Yogyakarta: Galang Press.

Sunardi, ST. (2002). Semiotika Negativa. Yogyakarta: Buku Baik.

\section{Artikel}

Thawakal, Iqbal. “Atjungkan Tindju Kita: Lagu dan Sikap Politik Jaman Soekarno". Majalah Progress, No.1 Jilid 31993.

\section{Internet}

http://gin2.info/?p=54.

http://www.cybertokoh.com/mod.php?mod=p ublisher\&op=viewarticle\&artid=1178.

www.detikhot.com/index.php/tainment.read/ tahun/2006/bulan/05/tg1/19/time/183356/ idnews/598771/idkanal/229.

h t t p : / / w w w.te m p o.co/re a d / kolom/2014/02/14/1123/PerbandinganDua-Film-G30S.

\footnotetext{
${ }^{27}$ BJ Habibie (1998-1999), Abdurrahman Wahid (19992001), Megawati Soekarno Putri (2001-2004), dan Susilo Bambang Yudoyono (2004-2014).
} 